RESEARCH PAPER

\title{
"Creative solutions": selling cigarettes in a smoke-free world
}

\author{
E A Smith, R E Malone
}

Tobacco Control 2004;13:57-63

See end of article for authors' affiliations

.....................

Correspondence to: Elizabeth A Smith, PhD, Department of Social and Behavioral Sciences, Box 0612, Laurel Heights Campus, University of California San Francisco, San Francisco, CA 94143, USA;

libbys@itsa.ucsf.edu

Received 8 April 2003

Accepted 12 August 2003
Objective: To analyse the development and execution of the "Creative Solutions" Benson \& Hedges advertising campaign to understand its social, political, and commercial implications.

Methods: Searches of the Philip Morris documents and Legacy Tobacco Documents websites for relevant materials; Lexis/Nexis searches of major news and business publications; and denotative and connotative analyses of the advertising imagery.

Results: Philip Morris developed the Creative Solutions campaign in an effort to directly confront the successes of the tobacco control movement in establishing new laws and norms that promoted clean indoor air. The campaign's imagery attempted to help smokers and potential smokers overcome the physical and social downsides of smoking cigarettes by managing risk and resolving internal conflict. The slogans suggested a variety of ways for smokers to respond to restrictions on their habit. The campaign also featured information about the Accommodation Program, Philip Morris's attempt to organise opposition to clean indoor air laws.

Conclusion: The campaign was a commercial failure, with little impact on sales of the brand. Philip Morris got some exposure for the Accommodation Program and its anti-regulatory position. The lack of commercial response to the ads suggests that they were unable to successfully resolve the contradictions that smokers were increasingly experiencing and confirms the power of changing social norms to counter tobacco industry tactics.
C garette advertising has the commercial agenda of selling a brand, and the social agenda of promoting smoking. Such promotion requires resolving the contradictions associated with tobacco use. For example, many smokers start in adolescence to fit in socially, but clean indoor air laws and changing norms increasingly mean that smoking is not permitted in social settings. Cigarette advertising imagery must overcome this contradiction to enable smokers and potential smokers to justify adopting or maintaining the habit.

Cigarette companies also advertise to support their political agendas. These efforts frequently use "advertorials" - advertisements addressing a particular issue. However, it is rare for a tobacco company to combine political and product advertising. ${ }^{1}$

This study analyses a Philip Morris (now Altria) ${ }^{2}$ ad campaign that explicitly and implicitly merged commercial, social, and political agendas. These ads, which promoted Benson \& Hedges (B\&H) cigarettes in the USA from 1994 through 1996, were known internally as the "Creative solutions" campaign. The campaign aimed at helping smokers manage the physical and social risks of smoking, thus resolving the social contradictions created by clean indoor air laws. The ads also promoted Philip Morris's Accommodation Program, which undermined US efforts to establish clean indoor air laws and regulations. The campaign reveals Philip Morris's need to respond politically and commercially to tobacco control success at denormalising smoking.

\section{METHODS}

Data were collected from the Philip Morris Incorporated Document Website (http://www.pmdocs.com/) and Legacy Tobacco Documents Library (http://legacy.library.ucsf.edu), which provide access to millions of company documents released as a result of the multiple state attorneys general settlement and other cases. Between 11 July 2001 and 6 March 2003, we searched the websites for documents related to this ad campaign. We used a variety of search terms including "Creative Solutions," "Accommodation," and "Benson \& Hedges." Searches were extended using names of individuals, dates, and other indexing information in a "snowball" search strategy. Further information on document collections and searching strategies is provided in earlier work. ${ }^{3}$ In addition, major US newspapers were reviewed for the relevant period. Finally, the 13 different executions that constituted this ad campaign were acquired and their imagery analysed denotatively (that is, for the literal content of the ad) and connotatively (that is, for the meaning conveyed by the ad). This descriptive case study is based on a review of the advertisements, 430 industry documents, and Lexis/Nexis searches of over 50 newspapers.

\section{BACKGROUND}

In the late 1980s and early 1990s, the US tobacco control movement was having unprecedented success. In 1986, the Surgeon General issued a report declaring secondhand smoke to be a health hazard. ${ }^{4}$ The resulting transformation of smoking from a personal choice affecting only smokers to a social problem that endangered others fuelled the passage of clean indoor air laws. By 1993, when the Environmental Protection Agency identified secondhand smoke as a class A (human) carcinogen, ${ }^{5}$ over 800 such laws had been enacted. ${ }^{6}$ Media coverage was increasingly sympathetic to clean indoor air advocates and dismissive of the claims of tobacco spokespeople. $^{7}$ The climate for smoking was changing rapidly.

Meanwhile, Philip Morris was developing a new ad campaign for $\mathrm{B} \& \mathrm{H}$. The campaign for which $\mathrm{B} \& \mathrm{H}$ was best known was its first, "Oh, the Disadvantages". These ads humorously suggested that B\&H's $100 \mathrm{~mm}$ (extra long) length posed a variety of difficulties for its smokers (for 
example, getting caught in elevator doors), who nonetheless chose it for its taste. The brand did fairly well, rising to a $5 \%$ market share in 1983. ${ }^{8}$ However, by 1989, Philip Morris senior vice president of marketing David Dangoor was calling B\&H "our biggest brand challenge". ${ }^{9}$ The brand's share had dropped to a $2.5 \%$ share by $1993 .{ }^{10}$

In that year, $\mathrm{B} \& \mathrm{H}$ smokers were middle aged (over 35 years old), female, and "highly sensitive to anti-smoking pressure". They were leaving the brand by quitting, choosing cheaper brands, or switching to lower tar cigarettes. A report hypothesised that "In today's environment of anti-smoking fervor and smoker guilt...enjoyment and image may no longer be enough to create a switcher... advertising can only draw in new smokers or those competitive smokers who have convinced themselves to switch." ${ }^{11}$ In other words, switchers changed brands to reduce their guilt, so they moved to lower tar (perceived as healthier) or cheaper (better value) brands. ${ }^{12}$ Switching to a premium brand such as B\&H for "taste" or image was rare. So the brand team had to hold onto a market of middle-aged women and attract a much younger group (new smokers) as well as poorly defined, self-motivated switchers.

\section{EMPATHY}

The new B\&H advertising strategy was "Empathy": ads were to suggest that the brand "understood" smokers' feelings about the practical and social contradictions of smoking. Many ad campaigns invent problems for their products to solve-for example, "feminine hygiene." In the case of the "Disadvantages" ads for B\&H, because everyone recognised that the overlong cigarette "problem" wasn't real, there was no need to "solve" it. In the new B\&H ads, by contrast, Philip Morris used a real problem. The ads explicitly referenced smokers' difficulties with clean indoor air laws and regulations.

Meetings in June 1993 between premium brand manager Suzanne LeVan and Doug Porter of Leo Burnett, the advertising agency, focused on the message that "smoking B\&H 100 's...is worth the societal hassles...because of its great, quality taste [ellipses in original]." However, there was concern about "whether consumers really want to be reminded of the social pressures and constraints, and whether associating this environment with a brand is a positive thing."13 LeVan wondered if consumers "love it because it recognizes their daily hassles, or do they hate it because it reminds them of how terrible the situation is??? [sic]"14 But she told Porter her "hunch" was that they would "hit pay dirt" with the Empathy strategy. ${ }^{14}$

Under the Empathy rubric, three campaigns were developed. By early August, focus groups with people who smoked or might switch to $\mathrm{B} \& \mathrm{H}^{15}$ were testing preliminary executions of these conceptions, which were called "Apology", "Hurdles", and "Creative Solutions". Apology showed situations in which smokers were missing, presumably because they were out smoking (for example, an empty bank teller's cage). Clean indoor air rules were keeping smokers from their jobs. But focus group participants saw irresponsible smokers inconveniencing others. "Too many of our participants felt that these ads would further fuel negative attitudes and images about smokers... 'They're not doing their job, they're off having a cigarette."'16 The company dropped the Apology concept. ${ }^{16}{ }^{17}$ Another problem with this campaign was that it showed neither cigarettes nor smokers.

Hurdles showed the difficulties of getting to the smoking section, implying that smoking sections were excessively burdensome, and that $\mathrm{B} \& \mathrm{H}$ made the difficulty worthwhile. The "hurdles" included walking a tightrope high above a busy street, crossing a crocodile filled pond on stepping stones, and walking across a bed of burning coals (fig 1). ${ }^{18}$

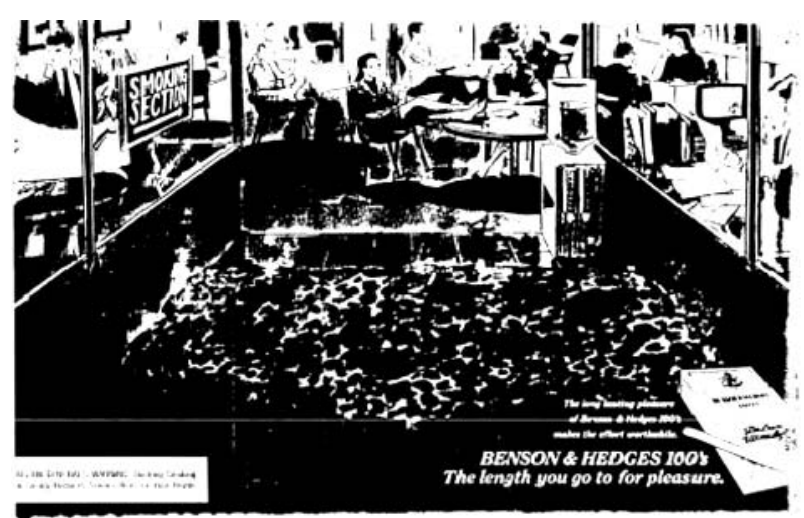

Figure 1 Hurdles: hot coals. (Benson \& Hedges 100's. The length you go to for pleasure. Philip Morris. 1993. Accessed 24 July 2002. Bates No. 204071 1554/1574. http://legacy.library.ucsf.edu/tid/wyj72e00)

Focus groups were both entertained and disturbed. The problem was that "the obstacles shown... appeared too great, not worth it." Some respondents "indicated if it came to that, I'd probably stop smoking altogether."'19 This was not the message that Philip Morris wanted to convey.

Creative Solutions suggested innovative places for smokers to light up, now that smoking was banned in the usual locations. Billboards and magazine ads showed crowds of happy smokers on top of moving trains, lounging in the hands of caryatids in the frieze of a building, perched on bunches of party balloons above festive throngs, dining on the ledges of an art deco building, and relaxing on the crown of the Statue of Liberty (figs 2-4). The tag line was "The length you go to for pleasure," referencing the cigarette's $100 \mathrm{~mm}$ length and suggesting that smokers were well rewarded by the cigarette for the trouble they had to take to smoke.

\section{MANAGING RISK}

The predominant unstated theme of the ads is managing the risks of smoking. Overall rates of smoking prevalence were declining steadily, ${ }^{20}$ but the industry attempted, through

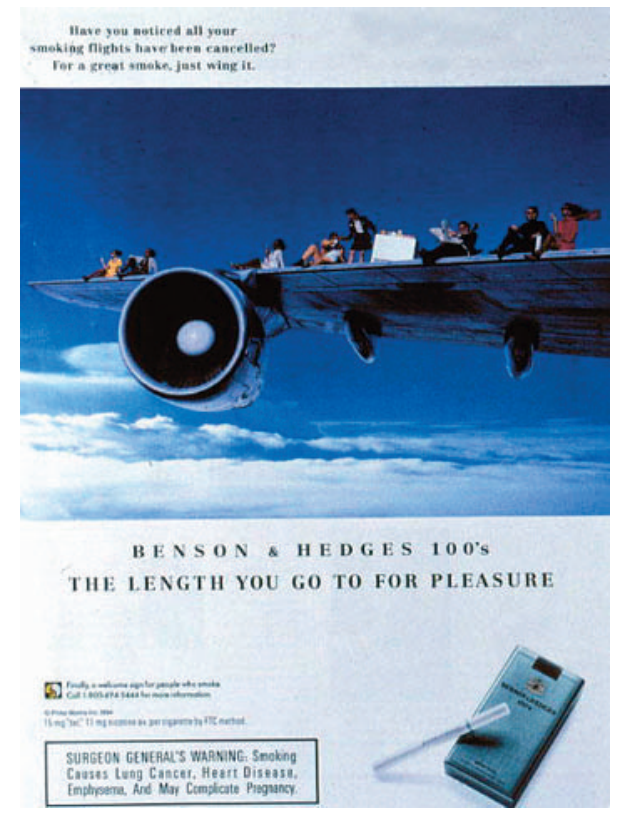

Figure 2 Creative solutions: airplane. 


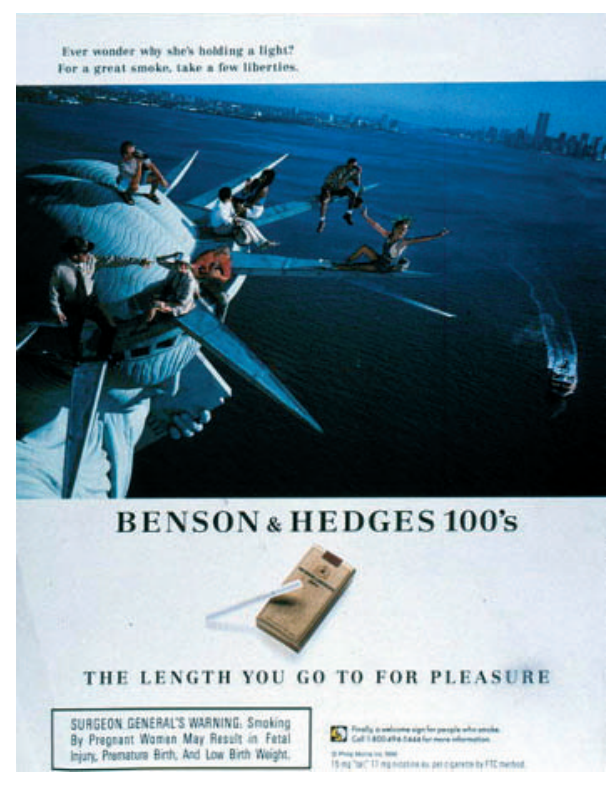

Figure 3 Creative solutions: Statue of Liberty.

advertising and the development of new products, to allay people's fears about the well known health risks. Such efforts generally focused on "low tar" cigarettes that implied reduced exposure to toxins. ${ }^{21-23}$

The $\mathrm{B} \& \mathrm{H}$ ads were subtler. The imagery focused on groups of people forced by strict clean air regulations to smoke in a variety of unlikely places. These locations were nearly always physically impossible (for example, the wing of a plane in flight, as shown in fig 2) or at least highly risky (the ledge of a building, as shown in fig 4). No safety precautions were visible. But even as the models were risking their lives for the opportunity to smoke, they were relaxed and comfortable. The draft on the airplane wing made reading a newspaper a bit tricky, but otherwise the ads show no inconvenience, let alone danger.

This imagery was a visual metaphor for the attitude the tobacco industry promotes about smoking: the risk is obvious, but insignificant. The people in the ads were not defying death or facing down danger. They were joyfully oblivious to it, and their insouciance made it disappear. These people were so comfortable, and their situations so preposterous, that it was possible to observe their pleasure without anxiety. The ads conveyed this cavalier attitude about the danger of falling off a speeding train, and the dangers of smoking were implicitly rendered just as trivial.

Social risk was also addressed in the ads. As smoking grew more unacceptable, non-smokers were empowered by laws, regulations, and social norms to ask smokers to put out their cigarettes. The accumulation of these interactions created tensions between smokers and non-smokers, and made smokers consider whether lighting up would relieve or add to their stress.

The $\mathrm{B} \& \mathrm{H}$ ads resolved this predicament by featuring nonsmokers in positions of authority. The non-smokers gave the smokers permission to be in their unusual locations and to smoke. A park ranger pointed out sights on the Statue of Liberty; $^{24}$ a conductor took tickets on top of the train; a waitress served customers in the sombrero sign over a taco stand; and a flight attendant dispensed drinks on the airplane wing. Other ads were subtler. The restaurant ledge was shared by a violinist playing for the patrons. The public building embodied its own approval of the smoker cradled in the hand of its caryatid. The executions showing purely social

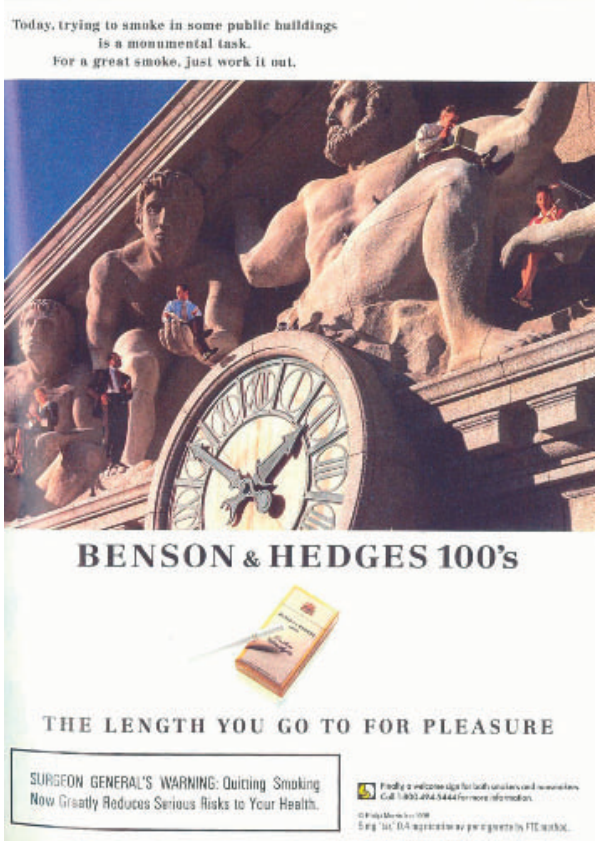

Figure 4 Creative solutions: public building.

situations (houses, clotheslines) were the exception-no authority figure was shown at home. Including non-smokers in the ads was a deliberate tactic to "minimize smoker alienation" and "sense of exclusion". ${ }^{24}$

Social risk was also minimised by the population of the ads. Whereas most cigarette ads show only a few people, these ads had between five and 19. And unlike most cigarette ads, particularly from this period, ${ }^{25}$ these used a mix of races and often generations. Focus group responses suggested there was comfort in numbers. The best ads depicted smokers as "the majority, 'popular' (not alone [or] in small groups)". ${ }^{19}$ Indeed, the number and mix of people served to suggest a whole society of smokers, with a few approving non-smokers, heightening the absurdity of the smokers' exile to their precarious locations.

The attitude of the smokers, as Philip Morris intended it, evoked "positive images about the 'smoking section' to link to consumers' desires to visualize: a positive self-image; a place I want to be." ${ }^{16}$ Leo Burnett concluded that "A better view, being able to enjoy a nice day, etc. all help in making the situation more appealing, but the expressions, posture and attitude of the smokers are the biggest indicator that they are in a better place." ${ }^{26}$ The relative height of the smoking sections suggested aspiration, as well as risk. Most of the non-smokers were invisible, and implicitly underneath-inside the Statue of Liberty, or the train, or the house. The smokers were on top of the world. Social exile was transformed into social desirability, the place everyone wanted to be.

\section{"SOLUTIONS" TO CLEAN INDOOR AIR}

The first line of the slogans used in the Creative Solutions ads pointed to the difficulties clean air laws and regulations posed to those used to smoking anywhere. Of the 13 different executions, eight referred to increasingly strict rules by using such words and phrases as "today", "these days", and "it's getting harder". The others emphasised the difficulties of smoking at work, on transportation, and at home or with friends.

The second lines of the slogans suggested a variety of solutions to the smokers' dilemma. The tone in which the 
"solutions" were proffered ranged from compromising to aggressive. Some executions used mild puns to emphasise the absurdity of the visuals: "Just wing it" on the airplane, for example. Two of the ads, Fast Food and Clothesline, proposed that smokers exit an unwelcoming venue. The Building and Party ads suggested that compromise was possible. However, the preceding clause "For a great smoke" or "For Benson \& Hedges 100s" made it clear that compromise did not mean not smoking.

Several of the ads were more assertive in content, urging smokers to stand up to the restrictions. The Statue of Liberty ad (fig 3) was the strongest (using a tremendous visual symbol for freedom), asking "Ever wonder why she's holding a light?" and telling smokers to "take a few liberties". An earlier version of the ad was even stronger: "If she didn't want us to smoke, why is she holding a light?"27 Thus the statue was a smoker, her torch a lighter, and her ideals "smoker's rights". The Cruise Ship ad said to "rock the boat" and Houses told smokers to "make yourself at home" - that is, ignore the rules. Perhaps the strongest proposed execution showed smokers picnicking on the moon. The copy read: "What happens when they've taken away all the places we used to enjoy Benson \& Hedges? We'll moon 'em."18 ("Mooning" is rudely exposing one's buttocks.) It was never produced for use, as the copy was found to be "inconsistent with B \& H imagery". ${ }^{16}$

Philip Morris spokespeople repeatedly referred to humour as part of $\mathrm{B} \& \mathrm{H}^{\prime}$ s brand equity (that is, one of the marketable "traits" for which the brand was known). ${ }^{28}{ }^{29}$ The old ads made exaggerated claims for the product and deflated them at the same time. Their joke was on the smokers, who chose their "plight" and were willing to laugh at themselves. By contrast, although the smokers in the Creative Solutions ads chose their predicament by insisting on smoking, the ad copy made it clear that outside forces were telling smokers to "ship out". In the face of these demands, the smokers found "a better place". ${ }^{19}$ They neither acknowledged the "disadvantages" nor laughed at themselves. The joke was on those who restricted them.

This attitude is important because the "problem" posed was real. Smokers could no longer smoke in many places, and there was no way that any brand could "solve" that problem. ${ }^{13}$ The most obvious solution to the social stresses of smoking was for smokers to quit. The smokers in the ads, therefore, couldn't allow the "problem" to bother them, which would bring quitting to mind.

\section{ACCOMMODATION}

The other "solution" was to reverse the trend of increasing restrictions. As concerned as Philip Morris was about sales, this policy agenda may have been more important. To advance it, Philip Morris used the B\&H ads to promote its "Accommodation Program". This was a very rare linkage of a product with a political message.

Begun on a trial basis in Pittsburgh in 1989, the Accommodation Program was supposed to give hospitality businesses-restaurants, hotels, bowling alleys, etc-a concrete alternative to banning smoking. ${ }^{30}$ The Program could be used by individual businesses, but more importantly, it provided a focus for organising to oppose local clean indoor air laws. Business owners could claim that such laws weren't needed because they were already "accommodating" smokers and non-smokers. On a practical level, the Program consisted of signs and stickers indicating that the establishment had both smoking and non-smoking sections. How these were implemented was up to the individual business. ${ }^{31}$

The Accommodation Program symbol (a yin-yang with a lit cigarette in one half) was featured in all English language Creative Solutions ads, along with a toll-free number (the
Spanish language versions did not feature the Accommodation Program). The text next to the symbol initially read, "Finally, a welcome sign for people who smoke" - a reference to Philip Morris's hope that the symbol would replace the universal "no smoking" circle and slash. Later, perhaps in an effort to add plausibility to the claim that Philip Morris also cared about those represented by the nonsmoking half of the icon, this was changed to "Finally, a welcome sign for both smokers and non-smokers".

\section{POLITICAL IMPLICATIONS}

Philip Morris was aware of the political implications of the ads. As they were being developed, the city of San Francisco passed a law prohibiting smoking in most workplaces. Even before the law went into effect on 1 February 1994, Philip Morris decided to "eliminate all Region 5 [west of Colorado] geographies from launch plan...due to the legislative environment in California". ${ }^{32-34}$ In addition, company executives were prepared to answer hypothetical questions that suggested that Philip Morris was "reduced to saying you understand how hated your customers have become" and asked whether their "customers are going to appreciate being reminded that smoking has made them pariahs". ${ }^{35}$ The company line about whether there was a political goal to the campaign was that the brand sought to "spread a message of accommodation for smokers and non-smokers alike".

\section{UNSOLVED PROBLEMS}

There were some problems with the Creative Solutions strategy. First, because B\&H could not "solve" the problem it referenced, it was difficult for the brand to "own the solution". Suzanne LeVan remarked that "we won't know whether we can make B\&H the proprietary owner of societal smoking empathy until we try" ${ }^{13}$ Smokers said that the Creative Solutions campaign "reminds you that smokers have rights, too", but saw B\&H as "the sponsor of a general cigarette category 'public service announcement" ${ }^{\prime \prime} .^{36}$

Another issue had to do with audience appeal. Cigarette companies analyse their customers in demographic terms (such as age, sex, and income) and "psychographic" categories that explain customers' motivations for smoking or brand choice. The educated, older women who made up B\&H's core demographic tended to be "guilt-laden" about smoking. ${ }^{37}$ But the campaign appealed most to "proud" smokers ${ }^{36}{ }^{38}$ who "appreciated seeing 'a brand crusading for our rights"'.36 These smokers were less educated and poorer, and they did not smoke B\&H. ${ }^{38}$ Thus, there was a conflict between the stated goal of appealing to current B\&H smokers to stanch the outflow of quitters and switchers, and continuing with the Creative Solutions campaign, which resonated with a different market.

A third problem had to do with the campaign's potential for longevity. One of B\&H's problems was its plethora of ad campaigns and lack of stable identity. ${ }^{39}{ }^{40}$ Creative Solutions was supposed to "establish a long-term image for the brand". ${ }^{41} 42$ In theory, Creative Solutions had that potential, as a 1989 marketing report suggested. A brand that "focuses on the restrictions" could actually benefit from stricter indoor air rules, since "As the restrictions become more intense-the toughening of the rules automatically promotes the image ${ }^{\prime \prime}{ }^{43}$

Thirteen different Creative Solutions ads were produced; more were proposed and rejected. Some of the rejects were insufficiently "aspirational" (middle class), such as an ad showing a bus. ${ }^{19445}$ The Creative Solutions had to be "not immediately associated with segregationalism [sic]." Indeed, some respondents felt the height of all the smoking sections implied "isolation", "punishment", or being "stuck out of the way". ${ }^{16}$ The best ads depicted "situations in which smoker 'controls' risk". ${ }^{19}$ The ads also had to refer to a genuinely 
experienced restriction. Focus groups rejected executions that depicted situations in which they did not want or never expected to smoke. Among these were ads about elevators, ${ }^{46}{ }^{47}$ shopping, ${ }^{48}$ and libraries. ${ }^{24}{ }^{49}$ Use of situations in which smoking was not yet restricted was too threatening, suggesting that the climate for smokers would get worse. Ads rejected on this count depicted a piano bar, ${ }^{50}$ a stadium, ${ }^{51}$ a diner, ${ }^{49}$ and a hotel. ${ }^{51}$

Finally, although the "problems" had to have an element of realism, the "solutions" had to be fantastic or they risked descending into a prosaic suggestion for creating a smoking section. ${ }^{24}$ The other possibility for insufficiently imaginative "solutions" was that they would, given the element of risk present, become an occasion of fear. Some focus group respondents were made nervous by the "Train" execution because it seemed too "possible". ${ }^{52}$

The campaign may also have overestimated the rebelliousness of smokers. Many smokers accepted smoke-free areas. For example, one respondent said: "I don't even smoke in my own house anymore, so how can I mind when people ask me to smoke outside their house?"52 Smokers in a gay focus group agreed, saying that they preferred smoke-free flights and restaurant sections. ${ }^{53}$ Resistance to the ads was clearest among Hispanics, who believed that sociability and conformity were more important than asserting individual rights. ${ }^{54}{ }^{55}$ These attitudes left Hispanic smokers unreceptive to the Creative Solutions ads. For these smokers, the headline copy was "a negative reminder of the currently imposed smoking restrictions" and the visuals were "viewed literally and thus seen as absurd, extreme, risky, or dangerous". The smokers in the airplane ad, for instance, "were seen as pathetically desperate" ${ }^{\prime 56}$

Philip Morris would have liked their customers to be less compliant, which led to miscalculations such as the "Moon" ad. ${ }^{19}$ The most striking example of the distance between the industry and the consumer perspective arose with the "Restaurant" execution. The original line on this ad was "Why are most restaurant smoking sections so unappetizing?". ${ }^{57}$ But "some smokers did not 'get' the line, interpreting it as a critique". ${ }^{47}$ The line was eventually changed to read, "The only thing allowed to smoke in some restaurants these days is the grill". Smokers were not as unselfconsciously positive about smoking as Philip Morris was.

\section{SELLING CIGARETTES}

The ads failed to hit "a home run" ${ }^{\text {"58-61 }}$ for the brand. Although B\&H experienced a slight upturn in early 1995, the campaign ended with an approximately 0.2 market share loss. ${ }^{8}$ Neither did the ads provide a long lasting brand identity. Philip Morris was initially upbeat about the ads' effect on brand recognition, ${ }^{34}$ but in a July 1994 focus group B\&H smokers could not describe the current ads. When shown the ads, participants recognised them, but didn't associate them with $\mathrm{B} \& \mathrm{H} .{ }^{24}$ The Creative Solutions campaign lasted only two years. By 1996 a completely new set of ads was running, featuring anthropomorphised cigarettes engaged in leisure activities.

The campaign may have had some success "reinforc[ing] messages re: desirability of accommodating smokers and non-smokers alike". ${ }^{62}$ Media coverage of the ads was generally positive. The New York Times found the ads "whimsical". ${ }^{63}$ Brandweek's story, though it noted the lethal nature of smoking, described the ads as "encouraging a defiant, social incorrectness". ${ }^{64}$ Superbrands called the ads "witty" 65 and the Washington Post said they were "lighthearted mischief". ${ }^{66}$ When USA Today asked ad agencies to pick the best ads of the year, Creative Solutions made the top $10{ }^{67}$ The positive slant was unusual at a time when media coverage in general was unsympathetic to the industry's position on secondhand smoke. ${ }^{7}$ However, it is doubtful that the ads significantly increased public sympathy for smokers or opposition to clean indoor air laws.

The ads were moderately successful at promoting the Accommodation Program. Philip Morris tracked the number of calls to the Accommodation line that were prompted by the ads. In 1994, the year the campaign began, they received approximately 30500 such calls. ${ }^{68}$ The next year they received 39000 , but in 1996 only 19000 calls came in. ${ }^{69}$ The evidence from one focus group suggested that readers rarely noticed the symbol and phone number. ${ }^{24}$ Additionally, the primary market for the Accommodation Program was not consumers but business owners, so consumer advertising was a scattershot approach.

\section{DISCUSSION AND CONCLUSIONS}

In the USA in the early 1990s, Philip Morris was undergoing a crisis brought on by declining smoking rates, an increasingly strict regulatory environment, and growing social disapproval. In response to these pressures, top executives and the corporate affairs department developed a variety of plans, from spinning off the cigarette business ${ }^{70}$ to giving the company an image makeover, ${ }^{2}$ to fighting back even more fiercely. ${ }^{71}{ }^{72}$ The Creative Solutions campaign demonstrates that advertising and marketing personnel responded to the political pressures as well.

The campaign illustrates the company's concern about the changing social norms around smoking. Contrary to the often stated industry assertion that smoking is an "individual choice", these ads and documents show that Philip Morris understood the importance of the social context for that "choice". The ads reassured smokers-and potential smokers-that the social pressures they were feeling did not mean they had to quit. The ads told non-smokers that their quest for clean indoor air was unreasonable. Philip Morris was promoting the social proposition that smokers had a "right" to their habit.

Better understanding of the way tobacco companies use imagery may help activists counter a variety of advertising and promotional strategies from the industry. The campaign under discussion may be particularly interesting in this regard because of its explicit and implicit blending of commercial and sociopolitical messages. The Creative Solutions campaign may be an anomaly; on the other hand, it may be a slightly open window into a common but subtle industry practice. Examining cigarette ads for their sociopolitical implications may add to our knowledge of how the industry achieves its objectives, and what opposition is most effective.

The mythic function of advertising is "to provide a model of thought capable of overcoming contradiction generated by society". ${ }^{73}$ The contradiction being addressed by the Creative Solutions ads was the changing role of smoking. Cigarette ads have to overcome their context to convince people that, even as the product's social utility wanes and its dangers become more obvious, it is still worth it to smoke.

Most cigarette ads attempt this by ignoring the larger context. The people in the ads live in a world in which everyone smokes at social occasions and no one thinks about cancer, heart disease, or polluted air. The stated or implied pleasures of smoking— "taste," "relaxation," "fun"-in most ads have not significantly changed in the last 20 years. There is no problem in most cigarette ads-just "pleasure".

The Creative Solutions ads, despite their surrealism, moved cigarette advertising much closer to the real world where smoking is no longer taken for granted. These ads attempted to grapple directly with the contradiction rather than ignoring it. The hopes of the brand team at Philip Morris were that smokers and would-be smokers would be relieved 


\section{What this paper adds}

Previous studies have largely focused on quantitative analyses of advertising imagery. These studies provide important information about trends in advertising themes and content, enabling advocates to trace the use of cartoon characters, health related terminology, and the like. These studies have generally shown how the industry has succeeded in promoting its product (for example, children's recognition of advertising icons).

Use of the tobacco industry documents to aid in the analysis of a particular campaign allows a richer, more nuanced interpretation of the ads. The documents reveal the motives, concerns, and difficulties of the company in its efforts to develop a message that would resonate with its customers. This campaign is particularly revealing, first, because it was a failure, and second, because it was a rare attempt to explicitly merge commercial and political agendas.

to see their problem acknowledged, and enjoy the fantasy solutions. But the ads were not up to the challenge; as visually appealing as they were, the reality of clean indoor air overcame the fantasy when smokers went to light up. The Creative Solutions ads and their evident failure speak volumes about the power of denormalisation to frustrate the industry's goals.

\section{ACKNOWLEDGEMENTS}

We would like to thank Naphtali Offen, Nathaniel Wander, Valerie Yerger, and Randy Wilson for their comments and suggestions. This study was funded by the National Cancer Institute, CA090789.

\section{Authors' affiliations}

E A Smith, R E Malone, Department of Social \& Behavioral Sciences, School of Nursing, University of California, San Francisco, San Francisco, California, USA

\section{REFERENCES}

1 Warner KE, Butler J, Cummings KM, et al. Report of the Tobacco Policy Research Study Group on tobacco marketing and promotion. Tobacco Control 1992; 1:S19-23.

2 Smith EA, Malone RE. Altria means tobacco: Philip Morris's identity crisis. Am J Public Health 2003;93:553-6.

3 Malone RE, Balbach ED. Tobacco industry documents: treasure trove or quagmire? Tobacco Control 2000;9(3):334-8.

4 US Department of Health and Human Services. The health consequences of involuntary smoking. A report of the Surgeon General, 1986. Rockville, Maryland: Public Health Service, Centers for Disease Control, 1986. (DHHS Publication No (CDC) 87-8398.)

5 Environmental Protection Agency. Respiratory health effects of passive smoking: lung cancer and other disorders. Washington DC: Environmental Protection Agency, 1992.

6 American Nonsmokers' Rights Foundation. Municipalities with clean indoor air ordinances. Berkeley, California: ANRF, 2002.

7 Malone R, Boyd E, Bero L. Journalists' constructions of passive smoking as a social problem. Social Studies of Science 2000;30:713-35.

8 Weinstein B. Interaction of media expenditures vs market share for major brands. 10 Nov 1991. Bates No. 2048400480/0493. http:// legacy.library.ucsf.edu/tid/zdr26e00

9 Dangoor DER. Benson \& Hedges task force. 26 Jul 1989. Bates No. 2040305064/5065. http://legacy.library.ucsf.edu/tid/cet05e00

10 Gawronski E. Cigarette shipment brand share report-951100. $18 \mathrm{Dec}$ 1995. Bates No. 2048024553/4591. http://legacy.library.ucsf.edu/tid/ ocs65e00

11 Preliminary thoughts on Benson \& Hedges. Oct 1989. Bates No. 2040790379/0386. http://legacy.library.ucsf.edu/tid/gvr93e00

12 Benson and Hedges 100's creative brief. 1992. Bates No. 2021152501/ 2502. http://legacy.library.ucsf.edu/tid/glh34e00

13 [Letter to Doug Porter re: Empathy strategy]. 22 Jun 1993. Bates No. 2045482324/2325. http://legacy.library.ucsf.edu/tid/zyi75e00

14 LeVan S. For your information red yellow green 930707. 7 Jul 1993. Bates No. 2045831093. http://legacy.library.ucsf.edu/tid/ksh92e00

15 Bonhomme J, Teitelbaum S. Benson \& Hedges qualitative copy development research plan. $20 \mathrm{Jul}$ 1993. Bates No. 2047255954/5955. http:// legacy.library.ucsf.edu/tid/zat17e00
16 Levine B. Summary findings memorandum B\&H empathy advertising positioning Tampa focus groups. 9 Aug 1993. Bates No. 2047255971/ 5980. http://legacy.library.ucsf.edu://tid/abt17e00

17 Bonhomme J, Munsterman N. Research learning on Benson \& Hedges 100's empathy strategy/creative. 23 Aug 1993. Bates No. 2504054014/4022. http://legacy.library.ucsf.edu/tid/tfv19e00

18 Benson \& Hedges 100's. The length you go to for pleasure. 1993. Bates No. 204071 1554/1574. http://legacy.library.ucsf.edu/tid/wyj72e00

19 Munsterman N. Research learning on Benson \& Hedges 100's empathy strategy/creative. 12 Aug 1993. Bates No. 2047255984/5992. http:// legacy.library.ucsf.edu/tid/wat $17 \mathrm{e} 00$

20 Department of Health and Human Services. Reducing tobacco use: a report of the Surgeon General. Washington DC: US Department of Health and Human Services, Centers for Disease Control and Prevention, National Center for Chronic Disease Prevention and Health Promotion, Office on Smoking and Health, 2000.

21 Warner KE. Tobacco industry response to public-health concern-a contentanalysis of cigarette ads. Health Education Quarterly 1985;12:115-27.

22 Pollay RW. Targeting youth and concerned smokers: evidence from Canadian tobacco industry documents. Tobacco Control 2000;9:136-47.

23 Pollay RW, Dewhirst T. The dark side of marketing seemingly "Light" cigarettes: successful images and failed fact. Tobacco Contro 2002;11 (suppl I):i18-31.

24 Guiles C. Benson \& Hedges advertising pretesting "creative solutions" next stages' 940700. Jul 1994. Bates No. 2047278198/8227. http:// legacy.library.ucsf.edu/tid/gzf16e00

25 Schooler C, Basil MD, Altman DG. Alcohol and cigarette advertising on billboards: Targeting with social cues. Health Communication 1996;8:109-29.

26 Hassman J. Benson \& Hedges research learnings. 2 Aug 1995. Bates No. 2048131501/1503. http://legacy.library.ucsf.edu/tid/emm 16e00

27 Benson \& Hedges 'smoking pleasure' - pool III shoot pre-production meting 'statue' 'rain' 'clothesline'. 8 Aug 1994. Bates No. 2045651060/1112. http://legacy.library.ucsf.edu/tid/hsr81fOO

28 Daragan K. [Letter to Stuart (Elliott)]. 29 Mar 1994. Bates No. 2062340008. http://www.pmdocs.com/getallimg.asp? if = avpidx\&DOCID $=2062340008$

29 Benson \& Hedges Empathy campaign message track (customer-directed) 1994. Bates No. 2062340015/0017. http://legacy.library.ucsf.edu/tid/ fmn67d00/getallimg. asp? if = avpidx\&DOCID $=2062340008 / 0017$

30 Samuels B, Begay ME, Hazan AR, et al. Philip Morris's failed experiment in Pittsburgh. Journal of Health Politics, Policy and Law 1992;17:329-51.

31 Task force meeting agenda. 1994. Bates No. 2044429655/9673. http:// legacy.library.ucsf.edu/tid/cwc16e00

32 Andersen B. Service report No. 45. 13 Jan 1994. Bates No. 2041867705/ 7708. http://legacy.library.ucsf.edu/tid/smq66e00

33 Anon. [Handwritten notes: empathy]. Sep 1993. Bates No. 2047828395/ 8403. http://legacy.library.ucsf.edu/tid/gkf75e00

34 LeVan S. B\&H advertising. 24 May 1994. Bates No. 2045482149. http:// legacy.library.ucsf.edu/tid/kaj75e00

35 Benson \& Hedges Q and A-revised 940329. 29 Mar 1994. Bates No. 2045651254/1257. http://legacy.library.ucsf.edu/tid/dsb82e00

36 Bonhomme J, Munsterman N. Research learning on Benson \& Hedges empathy strategy/creative. 23 Aug 1993. Bates No. 2040711545/1553. http://legacy.library.ucsf.edu/tid/vyi72e00

37 Anon. [Benson \& Hedges brand personality statement]. 30 Sep 1989. Bates No. $2021152839 / 2844$. http://legacy.library.ucsf.edu/tid/kzq88e00

38 Munsterman N. Identifying 'beleagured' 100's smokers for media. 26 Aug 1993. Bates No. 2047256187/6188. http://legacy.library.ucsf.edu/tid/ gat $17 \mathrm{e} 00$

39 Benson \& Hedges Task Force. Benson \& Hedges task force presentation. Aug 1989. Bates No. 2045353003/3046. http://legacy.library.ucsf.edu/tid/ xqd65e00

40 Anon. Benson \& Hedges 5 year plan. Aug 1989. Bates No. 2040329957/ 9966. http://legacy.library.ucsf.edu/tid/yfz94e00

41 Anon. Benson \& Hedges 940000 media plan review presented to Suzanne Levan. 20 Apr 1994. Bates No. 2041620366/0412. http:// legacy.library.ucsf.edu/tid/udd86e00

42 Philip Morris. Benson \& Hedges brand platform. 14 Jun 1993. Bates No. 20443531 15. http://legacy.library.ucsf.edu/tid/nkl97d00

43 Kelly Weedon Shute Advertising. Philip Morris cigarette marketing-a new perspective. Nov 1989. Bates No. 2501057693/7719. http:// legacy.library.ucsf.edu/tid/Iti49e00

44 Rodriguez Y. B\&H creative solutions qualitative research-final report. 24 Jan 1994. Bates No. 2040745064/5065. http://legacy.library.ucsf.edu/tid/ cah76e00

45 Greenfield Consulting Group. Benson and Hedges advertising development research (Phase III) qualitative research. Jan 1994. Bates No. 2504053947/ 3956. http://legacy.library.ucsf.edu/tid/mgv19e00

46 Greenfield Consulting Group. Benson and Hedges advertising development research (Phase II) qualitative research. Sep 1993. Bates No. 2504053995/ 4004. http://legacy.library.ucsf.edu/tid/dgv19e00

47 Bonhomme J, Rodriguez Y. 'Creative solutions' qualitative research-final report. 24 Sep 1993. Bates No. 2504053987/3989. http:// legacy.library.ucsf.edu/tid/cgx32e00

48 d'Albis P. B\&H Creative Solutions new execution qualitative research: Topline findings. 3 Mar 1994. Bates No. 2047277643/7647. http:// legacy.library.ucsf.edu/tid/ifx82e00

49 Bonhomme J. 'Creative Solutions' - qualitative research findings. 4 Aug 1994. Bates No. 2049185503/5504. http://legacy.library.ucsf.edu/tid/ sui93e00 
50 Andersen B. Service report no. 57 Philip Morris. 13 Jun 1994. Bates No. 2045651 127/1128. http://legacy.library.ucsf.edu/tid/voh92e00

51 Douglas. Service report [no. 46]. 3 Feb 1994. Bates No. 2045651309/ 1310. http://legacy.library.ucsf.edu/tid/opr26e00

52 Guiles C. Benson \& Hedges advertising pretesting 'creative solutions' next stages 940700. Jul 1994. Bates No. 2041793225/3256. http:// legacy.library.ucsf.edu/tid/hdr66e00

53 Guiles+Associates. Exploratory qualitative research: 'Benson \& Hedges in the gay market'. Feb 1994. Bates No. 2504053916/3938. http:// legacy.library.ucsf.edu/tid/ygv19e00

54 Market Developments. Qualitative research among Cubans in Miami reactions to proposed Spanish-language print ads for Benson \& Hedges. Nov 1993. Bates No. 2504053965/3976. http://legacy.library.ucsf.edu/tid/ zfx32e00

55 Qualitative research: cultural evaluation of the Benson \& Hedges 'creative solutions' campaign: its potential adaptation for Spanish advertising. Oct 1993. Bates No. 2047263791/3809. http://legacy.library.ucsf.edu/tid/ jis81f00

56 Market Developments. Qualitative research among Cubans in Miami reactions to proposed Spanish-language print ads for Benson \& Hedges. Nov 1993. Bates No. 2047263829/3865. http://legacy.library.ucsf.edu/tid/ yhs81f00

57 Anon. Why are most restaurants smoking sections so unappetizing? Jan 1994. Bates No. 2047264484. http://legacy.library.ucsf.edu/tid/ zkb82e00

58 Andersen B. Service report no. 34. 9 Sep 1993. Bates No. 2041867777/ 7778. http://legacy.library.ucsf.edu/tid/oxq66e00

59 Andersen B. Service report no. 35 [32]. 25 Aug 1993. Bates No. 2044353073. http://legacy.library.ucsf.edu/tid/noo03e00
60 LeVan S. For your information red yellow green [930927]. 27 Sep 1993. Bates No. 2045831119/1120. http://legacy.library.ucsf.edu/tid/ath92e00

61 LeVan S. Red yellow green. 15 Nov 1993. Bates No. 2040417141/7142 http://legacy.library.ucsf.edu/tid/wps62e00

62 Burson-Marsteller. Benson \& Hedges ad campaign media relations plan. 3 Mar 1994. Bates No. 2047828381/8394. http://legacy.library.ucsf.edu/ $\mathrm{tid} / \mathrm{dj} f 75 \mathrm{e} 00$

63 Goldman K. Philip Morris ads poke fun at restrictions. The New York Times 1994 March;30:B6.

64 Bissell J. How do you market an image brand when the image falls out of favor? Brandweek 1994;35(23): 16.

65 Warner F. Find a niche then defend it. Superbrands 1994;(suppl):133.

66 Mathews J. Poking fun at the puff patrol. Washington Post 1994 November; 19:D1

67 Horovitz B. Madison Avenue rates the ads of 94. USA Today 1995 December 29:1B

68 The Accommodation Program Accommodation Program Logo/B\&H adsconsumer call content. 10 Dec 1994. Bates No. 2044324335. http:// legacy.library.ucsf.edu/tid/dva58d00

69 Briggs G. 960000 accommodation program call volume summary. 29 Jan 1997. Bates No. 2071743370/3385. http://legacy.library.ucsf.edu/tid/ cup06c00

70 Smith EA, Malone RE. Thinking the 'unthinkable': Why Philip Morris considered quitting. Tobacco Control 2003;12:208-13.

71 Ferocious defense of the tobacco industry. Sep 1993. Bates No. 2022886999/7000. http://legacy.library.ucsf.edu/tid/qrc78e00

72 Miles MA. Ferocious defense. 7 July 1994. Bates No. 2022843127/3128. http://legacy.library.ucsf.edu/tid/apo44e00

73 Chapman S. Advertising and psychotropic drugs: the place of myth in ideological reproduction. Soc Sci Med 1979;13A:751-64. 